\title{
Governance of the emerging bio-energy markets
}

\author{
M. Verdonk ${ }^{\mathrm{a}, *}$, C. Dieperink ${ }^{\mathrm{b}}$, A.P.C. Faaij \\ ${ }^{a}$ Department of Water and Energy, Grontmij Nederland BV, P.O. Box 203, 3730 AE, De Bilt, The Netherlands \\ ${ }^{\mathrm{b}}$ Department of Innovation and Environmental Studies, Copernicus Institute for Sustainable Development and Innovation, \\ Utrecht University, P.O. Box 80.115, 3508 TC, Utrecht, The Netherlands \\ ${ }^{\mathrm{c}}$ Department of Science, Technology and Society, Copernicus Institute for Sustainable Development and Innovation, \\ Utrecht University, P.O. Box 80.115, 3508 TC, Utrecht, The Netherlands
}

Received 3 August 2006; accepted 22 December 2006

Available online 19 March 2007

\begin{abstract}
Despite its promising prospects, a growing global bio-energy market may have sustainability risks as well. Governing this market with respect to installing safeguards to ensure sustainable biomass production might reduce these risks. Therefore, proposals for governance systems for bio-energy are discussed in this article. The proposals are based on comparative case study research on the governance of comparable commodities. By assessing the governance system of global coffee trade, fair trade coffee, the global and the EU sugar market and Forest Stewardship Council (FSC) wood, strong and weak points of governance systems for commodities are discerned. FSC is selected as the best performing case study and serves as the proposal's basis. FSC's weaknesses are minimized by, among others, using the lessons learned from the other case studies. This results in a system consisting of two pillars, a bio-energy labelling organization (BLO) and a United Nations Agreement on Bio-energy (UNAB). Although consulted experts in the research process are critical about this system they do suggest several conditions a governance system for bio-energy should meet in order to be effective, such as a facilitative government, professional monitoring and using progressive certification combined with price premiums. These conditions have been taken into account in the final proposal.
\end{abstract}

(C) 2007 Elsevier Ltd. All rights reserved.

Keywords: Bio-energy; Sustainability; Governance

\section{Introduction}

Bio-energy is a promising tool for achieving a sustainable development. Using bio-energy can help to mitigate greenhouse gas emissions, as bio-energy can be a climate neutral source of energy. In order to lessen the dependence on fossil fuels, bio-energy can increase the supply diversity and security of energy. Bio-energy is also increasingly becoming more cost-competitive, compared to other sources of energy. Furthermore, bio-energy may help to alleviate rural poverty especially in developing regions, when bio-energy production is stimulated (WWI, 2006). Driven by these potentials, governments, but also private parties (e.g. utility/fuel companies, NGOs), are increasingly interested in using bio-energy as an alternative source of

\footnotetext{
${ }^{*}$ Corresponding author. Tel.: + 31302207911 ; fax: + 31306956366 .

E-mail address: martijn.verdonk@grontmij.nl (M. Verdonk).
}

energy (Faaij et al., 2003, p. 4). Production and trading volumes are already rapidly growing. Faaij et al. (2003, p. 4) argue that bio-energy markets may eventually evolve into a global bio-energy commodity market with linkages to other markets and related financial services within near future.

Despite the opportunities of bio-energy, there are concerns about the sustainability of bio-energy. It is feared that the production and trade of bio-energy may put great pressure on the Earth's natural resources, socio-economic conditions of producing regions and local food and energy availability. Table 1 shows the sustainability concerns that are identified by Lewandowski and Faaij (2004), emphasizing the potential threats of bio-energy. The concerns are grouped in four areas of concern.

Although some of these concerns are "traditional" to biomass production, other concerns can be explained by the unique characteristics of a (future) bio-energy market. 
Table 1

Bio-energy's sustainability concerns (based on Lewandowski and Faaij, 2004)

\begin{tabular}{|c|c|}
\hline Area of concern & Sustainability concern \\
\hline Land use patterns & $\begin{array}{l}\text { Deforestation } \\
\text { Unsustainable harvest regimes and yields } \\
\text { Natural habitats and landscape destruction } \\
\text { Regional food and energy supply shortages } \\
\text { Leakage effects (shift of unwanted activities) }\end{array}$ \\
\hline $\begin{array}{l}\text { Natural resources and } \\
\text { pollution }\end{array}$ & $\begin{array}{l}\text { Soil degradation } \\
\text { Use of GMOs instead of native species } \\
\text { Unsustainable agricultural production } \\
\text { methods } \\
\text { Water scarcity }\end{array}$ \\
\hline Socio-economic conditions & $\begin{array}{l}\text { Child labour is involved } \\
\text { Insufficient production remuneration } \\
\text { Poor perspectives for producers } \\
\text { Land tenure conflicts } \\
\text { Welfare of producing regions }\end{array}$ \\
\hline Others & $\begin{array}{l}\text { Environmental additionality } \\
\text { Traceability } \\
\text { Opportunities for local energy supply } \\
\text { development }\end{array}$ \\
\hline
\end{tabular}

First of all, virtually any agricultural and forestry biomass may end up as bio-energy. Therefore, feedstocks supplying the potential bio-energy market are extremely versatile. Secondly, both supply and demand potentials of bioenergy are huge. The availability of bio-energy in an extreme scenario could supply up to $50 \%$ of the global primary energy demand by 2050 (Hoogwijk et al., 2003), while energy demand may double by 2050 , compared to 2000 levels (Goldemberg and Johansson, 2004, p. 36). This future availability is uncertain as it depends on several factors, such as the future demand for food, livestock and open trade, the productivity of food production and forests and energy crops and availability of degraded land (Goldemberg and Johansson, 2004, p. 36). Despite these uncertainties, it is expected that the trade in energy crops will dominate the currently dominant trade in bio-energy from residues, as the supply potentials of energy crops are much larger than from residues (Faaij et al., 2003; Hoogwijk, 2004). Thirdly, trading patterns are expected to be extremely diversified, because the biomass for bioenergy may be produced anywhere. Fourthly, trading patterns are further complicated by alternative links of biomass to other markets, such as the food, fodder and timber markets. And, fifthly, raising end-user awareness on the sustainability of bio-energy may be more difficult, because all bio-energy ends up as fuel, electricity or heat, irrespective of the used feedstock. Food and timber products, for example, are more feedstock-recognizable and quality-valued products by end-users. These characteristics indicate that the potential scale and complexity of a (future) bio-energy market may be far greater than any agricultural market.
Palm-oil production is already an example of increased pressure on natural resources and local communities, because the rapid historic and future growth is accommodated solely through the expansion of large, mono-crop plantations at the cost of tropical forests (ProForest, 2003; Buckland, 2005). Questions can be raised not only about the environmental additionality of this practice (i.e. release of greenhouse gases from land use conversion), but also about its sustainability in a broader sense, relating to the concerns mentioned in Table 1. For instance, land tenure conflicts may arise when local communities are pushed from their lands and livelihoods by companies seeking expansion of their plantations. Forestry could become problematic as well, because the dominant production is expected to shift from Northern silviculture forests to Southern plantations in the coming decades (FAO in WWF, 2000). Some concerns of this development are that more natural habitats are lost, water scarcity is enhanced, land tenure conflicts arise, while local welfare improves little.

Despite these practices, developments and concerns, the use of bio-energy is promoted by most governments. The $\mathrm{EU}$, for example, has set the goal that $12 \%$ of the primary energy supply has to be met by renewable energy sources by 2010 (EC, 2001, p. 3). In the EU transportation sector, the use of bio-fuels has to be $5.75 \%$ of the total fuel consumed by 2010 (EC, 2003a). In most countries, bioenergy plays a dominant role in attaining the renewable energy objectives and bio-energy is, therefore, promoted by national policies and using various (financial) incentives (Lewandowski and Faaij, 2004).

When these concerns are not secured, bio-energy could turn into a threat instead of an opportunity for sustainability. This is also recognized by the Dutch government who has commissioned the Cramer Commission, to propose sustainability criteria for bio-energy production. These criteria are then incorporated in Dutch renewable energy policies. At the international level, however, there is currently no specific regulatory framework (or governance system) for the production and trade of bio-energy (WWI, 2006). We presume that a global governance system for bio-energy is needed to minimize the sustainability concerns, because of the potential scale of production, global trading patterns and potential risks of bio-energy. Governance should minimize possible negative impacts and maximize benefits.

Following Midttun $(1999,2004)$ three generic governance models for markets can be discerned. These models describe the relations between government, civil society and industries (or market). The main differences between the neo-liberal, welfare state and corporate social responsibility (CSR) model are summarized in Table 2.

The neo-liberal model is presented as a mainly decoupled style of governance, in which market forces dominate societal dynamics. Governments in this model have a minimalist role and civil society is mainly a "source" of an individualistic workforce and consumers. The Keynesian 
Table 2

Main characteristics of three models of governance by Midttun (1999, 2004)

\begin{tabular}{|c|c|c|c|}
\hline & Neo-liberal & Welfare State & $\mathrm{CSR}^{\mathrm{a}}$ \\
\hline Regulation & $\begin{array}{l}\text { Self-balancing } \\
\text { economy, laissez- } \\
\text { faire }\end{array}$ & $\begin{array}{l}\text { Governmental } \\
\text { intervention }\end{array}$ & $\begin{array}{l}\text { Soft } \\
\text { governmental } \\
\text { and market } \\
\text { endogenous } \\
\text { regulation }\end{array}$ \\
\hline $\begin{array}{l}\text { Role } \\
\text { industry }\end{array}$ & $\begin{array}{l}\text { Supplier of goods } \\
\text { and services }\end{array}$ & $\begin{array}{l}\text { Industrial partner } \\
\text { and employer }\end{array}$ & $\begin{array}{l}\text { Social partner } \\
\text { and supplier of } \\
\text { goods and } \\
\text { services }\end{array}$ \\
\hline $\begin{array}{l}\text { Role } \\
\text { government }\end{array}$ & $\begin{array}{l}\text { Minimalist } \\
\text { regulator of } \\
\text { market } \\
\text { imperfections }\end{array}$ & $\begin{array}{l}\text { Interventionist } \\
\text { and public service } \\
\text { provider }\end{array}$ & $\begin{array}{l}\text { Partner and } \\
\text { facilitator }\end{array}$ \\
\hline $\begin{array}{l}\text { Role civil } \\
\text { society }\end{array}$ & $\begin{array}{l}\text { Individualistic } \\
\text { workforce and } \\
\text { consumers }\end{array}$ & $\begin{array}{l}\text { Worker and } \\
\text { taxpayer }\end{array}$ & $\begin{array}{l}\text { Concerned and } \\
\text { organized } \\
\text { citizens/ } \\
\text { consumers }\end{array}$ \\
\hline $\begin{array}{l}\text { Meta } \\
\text { interaction }\end{array}$ & Decoupled & $\begin{array}{l}\text { Integration } \\
\text { through political } \\
\text { intermediation }\end{array}$ & $\begin{array}{l}\text { Integration } \\
\text { through informal } \\
\text { intermediation }\end{array}$ \\
\hline
\end{tabular}

${ }^{a}$ Midttun defines two models of CSR, this study uses the CSR I model only.

welfare model criticizes the concept of self-balancing economy and sees a substantial role for governments. Through governmental intervention, social and environmental issues are addressed. The market is regulated in order to realize social goods like full-employment. The CSR model seems to combine "the best of both worlds", emphasizing the self-regulatory capacities of the industry and civil society, while government has a more facilitating role. Such basic concepts can serve as a starting point for evaluating strengths and weaknesses of existing and developing markets. Because bio-energy markets are still developing and bio-energy governance systems are virtually absent, lessons can be learned from other, comparable commodities. These lessons can be used as policy advice on how bio-energy markets could be governed.

The aim of this article is to develop a proposal for a bioenergy governance system. This proposal is based on comparative case study research on the governance of comparable commodities and expert knowledge. For this purpose, the following question is central to this article: "What are the strengths and weaknesses of theoretically possible governance systems to regulate the international trade and production of bio-energy in a sustainable way?"

Three commodities have been chosen, represented by five case studies. By assessing the governance system of comparable commodities, strong and weak points are discerned. The cases are selected in the first paragraph of Section 2. The second paragraph describes the evaluation criteria and method. In the third section, the assessment results are presented. The best performing case study governance system is selected as the basis for the proposal. Using strengths of other case study governance systems helps to mitigate the weaknesses of this design. The preliminary proposal is evaluated ex-ante in the fifth section, in order to assess its fit on the bio-energy case and more specifically its feasibility and effectiveness. This was done by consulting experts. The ex ante evaluation resulted in several modifications of the proposal. A discussion and some recommendations follow the revised proposal for a governance system for bio energy.

\section{Methodology}

\subsection{Case study selection}

Selection of cases is based on two criteria. First, the governance system of the commodities should be an example of one of the three governance models. Secondly, the market and other characteristics of the commodities should be comparable to the characteristics of the emerging bio-energy market. Table 3 proposes the five case studies that are selected. Governance on the world market of coffee and sugar is an example of the neo-liberal model. The mainstream coffee market is selected, because (1) this is the most relevant coffee market in terms of volumes (Ponte, 2004, p. 11) and (2) the market is a liberalized market, where market mechanisms determine trade patterns, prices and the terms of trade and production (Ponte, 2002; ITC, 2005). The world sugar market is governed in a similar way as the mainstream coffee market (Larson and Borell, 2001, p. 1; NYBOT, 2005, p. 10). Trade patterns are more complicated, however, because both Northern and Southern countries produce and trade sugar (IIED et al., 2004, p. 76), making the world sugar market an interesting case for bio-energy that is also likely to have complicated trading patterns, especially for residues.

Fair Trade coffee and Forest Stewardship Council (FSC) certified wood are examples of the CSR model. In these markets NGOs and market actors cooperate to address broader societal issues. The FSC wood market is selected, because FSC is one of the world's most successful forest certification schemes (Atyi and Simula, 2002, p. 3). Fair Trade is one of the most significant CSR coffee markets

Table 3

Selected case studies

\begin{tabular}{ll}
\hline Model of governance & Case study \\
\hline Neo-liberal & $\begin{array}{l}\text { Mainstream coffee market } \\
\text { World sugar market }\end{array}$ \\
CSR & Fair Trade coffee market \\
& Forest Stewardship Council (FSC) market \\
Welfare-state & European Union (EU)'s sugar market \\
\hline
\end{tabular}


(Ponte, 2004). The EU plays a significant regulatory role on the European Sugar market, so this case exemplifies the welfare state model.

The selected cases share (some) characteristics with the bio-energy market. Coffee seems poorly comparable to bioenergy, because coffee is not a bio-energy feedstock and coffee is a more high-valued, low-voluminous commodity compared to bio-energy. Coffee has nevertheless been selected as a "comparable", because the coffee trading patterns may be highly comparable to bio-energy trade. Over $90 \%$ of the coffee is produced in the South, while the consumption happens mainly in industrialized countries (Ponte, 2002, p. 1101). Similarly, most energy crops may be produced in the South and consumed in the North, because Southern countries have high energy crop supply potentials (Hoogwijk, 2004) and Northern countries remain important destination markets. Additionally, as an agricultural commodity, coffee shares most bio-energy's sustainability concerns. Sugar and wood are chosen as comparable commodities for bio-energy, because these commodities are a significant feedstock for bio-energy, both on the short and long term and sugar and wood share most of the sustainability concerns of bio-energy.

\subsection{Evaluation method and criteria}

First we will assess the governance systems by evaluating their potential to secure the sustainability concerns defined in Table 1. Secondly, we will comment on the systems dependency, attractiveness, flexibility, costs, legitimacy and transparency, in order to indicate the performance of the governance systems on some broader issues. Table 4 gives an overview of the criteria and their indicators that have been developed for these broader issues. The sustainability concerns from Table 1 are grouped into four indicators (the "areas of concern"). The presence of chain regulation and the absence of anonymous exchange markets are thought to improve the ability to secure the sustainability concerns. The dependency of the governance system on certain (pre)conditions, may limit (or strengthen) the impact of the governance system on the market. Its attractiveness depends on the distribution of benefits and costs over the market actors. As bio-energy may be traded from regions with unique ecological, cultural and economic conditions, the governance system should have flexibility to accommodate local circumstances and needs. The governance system has certain associated costs and distribution of

Table 4

Evaluation criteria and indicators of broader issues

\begin{tabular}{ll}
\hline Criterion & Indicator \\
\hline Chain regulation & $\begin{array}{l}\text { Presence of anonymous exchange markets, curbing the effectiveness of private standa } \\
\text { Governance system governs the complete production chain }\end{array}$ \\
Dependency & Market is dependent on conscious consumers who are willing to pay a higher price \\
& Market paradigm is strengthened or propagated by a powerful institution \\
& Market paradigm is distorted by major barriers of entry \\
& Market mechanism is distorted by protectionism \\
& Market is dependent on a supranational institution
\end{tabular}

Attractiveness

Upstream actors are exposed to low and highly volatile prices Upstream actors have a weak negotiating power towards their buyers Downstream actors source directly from producers

High profit margins for downstream actors (who may be protected from price risk)

Market improves control and terms of trade in favour of upstream actors

Market improves control and terms of trade in favour of downstream actors

Market favours entrepreneurship as a result of little bureaucracy

Reputation of chain actors towards consumers is improved

Market is highly protected, depriving downstream actors of cheaper sources

Flexibility

Costs

Decision making at local and/or regional level at upstream nodes is featured Standards are fixed at above-regional level

Little fees, levies and/or taxes are imposed by governing institutions Burden of implementing and enforcing of rules and regulations is placed on chain actors Governance system is (partly) financed by the industry itself

Presence of artificial price interventions, potentially leading to overproduction Costs of promoting more sustainable products are carried by the governing institution Governance system is (partly) a form of foreign aid

Legitimacy

Transparency
Involvement of both upstream and downstream chain actors in decision making Governing institution is represented by democratic institutions

Monitoring is performed along the complete production chain Monitoring is performed by public or independent and transparent actor

\section{Scoring}

Yes $(-1)$, no $(1)$

Yes (1), no $(-1)$

Yes $(-1)$, no (1)

Yes (1), no $(-1)$

Yes $(-1)$, no (1)

Yes $(-1)$, no $(1)$

Yes $(-1)$, no (1)

Yes $(-1)$, no (1)

Yes $(-1)$, no (1)

Yes (1), no (-1)

Yes (1), no $(-1)$

Yes (1), no (-1)

Yes (1), no (-1)

Yes (1), no (-1)

Yes (1), no (-1)

Yes $(-1)$, no (1)

Yes (1), no $(-1)$

Yes $(-1)$, no (1)

Yes (1), no $(-1)$

Yes $(-1)$, no (1)

Yes (1), no $(-1)$

Yes $(-1)$, no (1)

Yes $(-1)$, no (1)

Yes $(-1)$, no (1)

Yes (1), no (-1)

Yes (1), no (-1)

Yes (1), no (-1)

Yes (1), no (-1)

When the indicator is not applicable the score is $(0)$. A " 1 " is considered as a strength and a " -1 " as a weakness, meaning respectively a contribution or a barrier to securing the sustainability concern. 
those costs over market actors. The legitimacy indicates the potential support for the governance system by politicians and market actors. And finally, the way monitoring is organized tells us something about the transparency of the governance system and its market. The implementation of the case study governance systems is not evaluated here; therefore, the proposal that is formulated in this article gives no assurance for a proper functioning of the governance system.

The method of evaluating the case studies to the extent the sustainability concerns are secured differs from the evaluation of the other evaluation criteria and indicators. In case of the sustainability criteria, the most relevant standards (policies, rules, laws, code of conduct or standard) of the case studies are identified and evaluated. Standards controlled by the leading or governing actors are considered the most relevant for the case study, because these actors have significant control over the market and/or its dynamic. These actors are identified by describing the case study market using the Global Commodity Chain (GCC) analysis from Gereffi and Korzeniewicz (1994). This network-based approach maps the market organization and its governance structure. A distinction is made between a producer- and a buyer-driven market (PDC and BDC). This distinction helps to identify the leading actors (those who "drive" the market), either up- or downstream in the production chain. Especially, in the case of the neoliberal model, where the institutional context of markets is of little relevance to chain regulation, leading actors must be identified in order to assess the governance system. As the neo-liberal cases are competitive markets, multiple leading actors are identified, who (together) control most of the market. In case of the EU sugar market, the Fair Trade coffee market and the FSC wood market the most relevant standards are found in the agreements or their institutions.

The identified standards are then evaluated for each sustainability concern. For each sustainability concern, a standard is scored according to the matrix in Table 5. The combination of the scope and the stringency indicate the extent a sustainability concern is secured. The scope means the extent to which the standard covers the concern. For

Table 5

Scoring matrix for securing the sustainability concerns

\begin{tabular}{lllll}
\hline Scope of standard & \multicolumn{3}{l}{ Stringency of standard } \\
\cline { 2 - 5 } & Common & Specific & Voluntary & - \\
\hline Fully addressed & 4 & 3 & 2 & - \\
Partly addressed & 3 & 2 & 1 & - \\
Addressed by local laws & - & - & - & 1 \\
Not addressed & - & - & - & 0 \\
\hline
\end{tabular}

The combination of the scope and the stringency indicate the extent a sustainability concern is secured in the evaluated standard. The higher the scoring, the better the sustainability concern is secured by the standard. When reference is made to locally applicable laws, the standard scores a " 1 ". When the concern is not addressed, the standard scores a " 0 ". example, addressing the use of chemical pesticides only, does not cover the concern of unsustainable production methods entirely. Stringency is indicated by whether the standard may be compulsory to everyone (common), compulsory to a specific group only (specific) or entirely voluntary (voluntary). The higher the scoring, the better the sustainability concern is secured by the standard. When the standard makes reference to locally applicable laws, the scope and stringency are more difficult to assess. In this case, the standard scores a "1" as it is assumed that local laws are less strict. When the concern is not addressed, the standard scores a " 0 ".

The results of the evaluation of the sustainability concerns are aggregated and presented in a percentage of the maximum score for each area of concern and for all sustainability concerns combined. In case a single governing actor operates multiple standards (such as the EU), then the highest score is used in the aggregation. The evaluation results of the other criteria on more broader issues are presented as a cumulative scoring. Although the scoring method is somewhat arbitrary, it does give a rough indication on the performance of the case study governance systems.

\section{Strengths and weaknesses of governance systems}

Tables 6-8 compare the assessment results and show that the discerned governance systems have strengths and weaknesses. Both neo-liberal governance systems (mainstream coffee market and the world sugar market) score comparatively lower than the governance system of the EU sugar market (the welfare state governance model) and the governance systems of FSC wood and Fair Trade Coffee (the CSR model).

\subsection{The mainstream coffee market}

The mainstream coffee market is by far the largest coffee market in the world, with a retail value share of almost $99 \%$ in 2000 (Ponte, 2004, p. 11). The market is characterized by a chronic oversupply of coffee and extreme price volatility due to sudden changes in harvesting expectations (NYBOT, 2004, p. 9; ITC, 2005; Ponte, 2002 , p. 1104). Price volatility is furthermore strengthened by trading markets with modern communication and transaction systems, where reactions are often sudden and simultaneous (ITC, 2005). The historically low coffee prices and its volatility are often referred to as the coffee crisis, which started at the end of the 1980s. Since the ending of the International Coffee Agreement in 1989, the mainstream coffee market is a liberalized market, where market places and actors determine prices and conditions of coffee production (Ponte, 2002, p. 1104). Beside regular cash markets, where ownership of coffee is traded, there are also futures markets, which are used by traders and manufacturers to protect profit margins against price fluctuations (ITC, 2005). 
Table 6

Relative performance of the governance systems

\begin{tabular}{|c|c|c|c|c|c|}
\hline Criteria & Fair trade coffee & Mainstream coffee & World sugar & EU sugar & FSC wood \\
\hline Securing sustainability concerns ( $\%$ of maximum total score) & $50 \%$ & $25 \%$ & $8 \%$ & $69 \%$ & $73 \%$ \\
\hline Broader issues (total score) & 6 & -2 & -3 & 3 & 6 \\
\hline
\end{tabular}

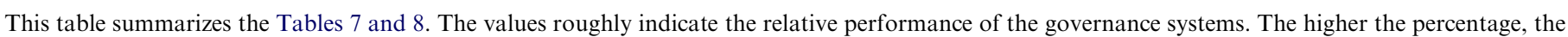

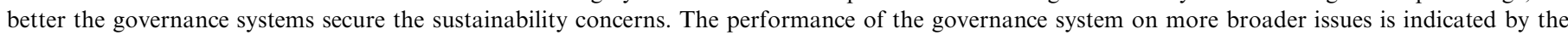

"total score" value. The more positive this value is, the better the governance system performs.

Table 7

Results of the sustainability evaluation

\begin{tabular}{|c|c|c|c|c|c|c|c|c|}
\hline \multirow[t]{2}{*}{ Sustainability concerns } & \multirow[t]{2}{*}{ Fair Trade coffee } & \multicolumn{3}{|c|}{ Mainstream coffee governance } & \multicolumn{2}{|c|}{ World sugar governance } & \multirow[t]{2}{*}{ EU sugar } & \multirow[t]{2}{*}{ FSC } \\
\hline & & Kraft Foods & Nestlé & Sara Lee & Unilever & S.A. & & \\
\hline \multicolumn{9}{|l|}{ Area of concern "land use patterns" } \\
\hline Deforestation & 1 & 0 & 0 & 1 & 1 & 0 & 3 & 4 \\
\hline Unsustainable harvesting and yields & 1 & 0 & 3 & 1 & 0 & 0 & 3 & 4 \\
\hline Natural habitats and landscape & 1 & 0 & 2 & 1 & 1 & 0 & 3 & 4 \\
\hline Regional food and energy supply shortages & 0 & 0 & 1 & 1 & 0 & 0 & 3 & 2 \\
\hline Leakage effects & 0 & 0 & 0 & 1 & 0 & 0 & 0 & 3 \\
\hline Subtotal ( $\%$ of maximum) & $15 \%$ & $0 \%$ & $30 \%$ & $25 \%$ & $10 \%$ & $0 \%$ & $60 \%$ & $85 \%$ \\
\hline \multicolumn{9}{|l|}{ Area of concern "Natural resources and pollution" } \\
\hline Occurrence of soil degradation & 3 & 0 & 3 & 1 & 0 & 0 & 4 & 4 \\
\hline Use of GMOs & 3 & 0 & 3 & 1 & 0 & 0 & 4 & 4 \\
\hline Unsustainable agricultural production methods & 3 & 0 & 3 & 1 & 0 & 0 & 3 & 3 \\
\hline Water scarcity & 3 & 0 & 3 & 1 & 3 & 0 & 4 & 4 \\
\hline Subtotal (\% of maximum) & $75 \%$ & $0 \%$ & $75 \%$ & $25 \%$ & $19 \%$ & $0 \%$ & $94 \%$ & $94 \%$ \\
\hline \multicolumn{9}{|l|}{ Area of concern "Socio-economic conditions" } \\
\hline Involved child labour & 4 & 4 & 4 & 4 & 4 & 0 & 4 & 3 \\
\hline Insufficient production remuneration & 4 & 0 & 3 & 3 & 0 & 0 & 4 & 3 \\
\hline Perspectives for producers & 4 & 0 & 3 & 0 & 0 & 0 & 3 & 0 \\
\hline Land tenure & 3 & 0 & 0 & 0 & 0 & 0 & 0 & 4 \\
\hline Welfare producing regions & 4 & 0 & 0 & 0 & 2 & 0 & 3 & 4 \\
\hline Subtotal ( $\%$ of maximum) & $95 \%$ & $20 \%$ & $50 \%$ & $35 \%$ & $30 \%$ & $0 \%$ & $70 \%$ & $70 \%$ \\
\hline \multicolumn{9}{|l|}{ Area of concern "Others" } \\
\hline Environmental additionality & 0 & 0 & 0 & 0 & 0 & 0 & 0 & 0 \\
\hline Traceability & 0 & 0 & 4 & 0 & 0 & 0 & 4 & 4 \\
\hline Opportunities for local energy supply development & 0 & 0 & 0 & 0 & 0 & 0 & 2 & 0 \\
\hline Subtotal ( $\%$ of maximum) & $0 \%$ & $0 \%$ & $33 \%$ & $0 \%$ & $0 \%$ & $0 \%$ & $50 \%$ & $33 \%$ \\
\hline Total ( $\%$ of maximum $)$ & $50 \%$ & $25 \%$ (average) & & & $8 \%$ (aver & & $69 \%$ & $73 \%$ \\
\hline
\end{tabular}

The most relevant case study standards are scored for each concern taking into account the scope and the stringency of the standards. The scoring matrix presented in Table 5 is used for this purpose. The higher the score and/or percentage, the better the sustainability concern is secured.

The mainstream coffee chain is organized and governed in a buyer-driven fashion, because the market is highly competitive and concentrated in the downstream nodes, where a few companies control much of the global market (Ponte, 2002). Although small farmers produce most coffee, the trend of consolidation in the downstream nodes also extends into the producing nodes where plantations and vertical integration are becoming more common (Ponte, 2002; ICO, 2001). Manufacturers, and to a lesser degree traders, control major barriers of entry and set the terms of trade, by practicing blending, "supplier-managed inventory", substitution and standard setting, backed-up by their market power (Lewin et al., 2004, p. 34; Ponte, 2002, p. 1108).
In the neo-liberal coffee market, the market actors themselves mainly regulate sustainability concerns. Since the mid-1990s the manufacturers are becoming more aware of their role in a sustainable coffee economy and have since then developed individual and some cooperative CSR policies (ITC, 2005; Kolk, 2005). However, the stringency and specificity of these CSR policies vary considerably (Kolk, 2005). As little cooperation and vertical integration exists in the coffee chain (ITC, 2005; Ponte, 2002), addressing the sustainability concerns throughout the chain often depends on the willingness to participate in chain regulation or standard setting by powerful downstream buyers.

Table 8 shows that governance of the mainstream coffee market scores high on dependency, attractiveness and 
Table 8

Evaluation results of broader issue criteria

\begin{tabular}{|c|c|c|c|c|c|c|}
\hline Criteria & Indicator & Fair Trade coffee & Mainstream coffee & World sugar & EU sugar & FSC wood \\
\hline \multirow[t]{3}{*}{ Chain regulation } & Presence of anonymous exchange markets, curbing the effectiveness of private standards & 1 & -1 & -1 & 1 & 1 \\
\hline & Governance system governs the complete production chain & 1 & -1 & -1 & 1 & 1 \\
\hline & Subtotal & 2 & -2 & -2 & 2 & 2 \\
\hline \multirow[t]{6}{*}{ Dependency } & Market is dependent on conscious consumers who are willing to pay a higher price & -1 & 1 & 1 & 1 & -1 \\
\hline & Market paradigm is strengthened or propagated by a powerful institution & -1 & 1 & 1 & 1 & -1 \\
\hline & Market paradigm is distorted by major barriers of entry & 1 & -1 & -1 & 1 & -1 \\
\hline & Market mechanism is distorted by protectionism & 1 & 1 & -1 & 1 & 1 \\
\hline & Market is dependent on a supranational institution & 1 & 1 & 1 & -1 & 1 \\
\hline & Subtotal & 1 & 3 & 1 & 3 & -1 \\
\hline \multirow[t]{10}{*}{ Attractiveness } & Upstream actors are exposed to low and highly volatile prices & 1 & -1 & -1 & 1 & 1 \\
\hline & Upstream actors have a weak negotiating power towards their buyers & 1 & -1 & -1 & 1 & -1 \\
\hline & Downstream actors source directly from producers & 1 & -1 & -1 & -1 & -1 \\
\hline & High profit margins for downstream actors (who may be protected from price risk) & -1 & 1 & 1 & -1 & 1 \\
\hline & Market improves control and terms of trade in favour of upstream actors & 1 & -1 & -1 & 1 & -1 \\
\hline & Market improves control and terms of trade in favour of downstream actors & -1 & 1 & 1 & -1 & 1 \\
\hline & Market favours entrepreneurship as a result of little bureaucracy & -1 & 1 & 1 & -1 & -1 \\
\hline & Reputation of chain actors towards consumers is improved & 1 & 0 & 0 & 0 & 1 \\
\hline & Market is highly protected, depriving downstream actors of cheaper sources & -1 & 1 & 1 & -1 & 1 \\
\hline & Subtotal & 1 & -1 & 0 & -2 & 1 \\
\hline \multirow[t]{3}{*}{ Flexibility } & Decision making at local and/or regional level at upstream nodes is featured & 1 & -1 & -1 & 1 & -1 \\
\hline & Standards are fixed at above-regional level & -1 & -1 & -1 & -1 & 1 \\
\hline & Subtotal & 0 & -2 & -2 & 0 & 0 \\
\hline \multirow[t]{7}{*}{ Costs } & Little fees, levies and/or taxes are imposed by governing institutions & -1 & 1 & 1 & -1 & -1 \\
\hline & Burden of implementing and enforcing of rules and regulations is placed on chain actors & 1 & -1 & -1 & 1 & -1 \\
\hline & Governance system is (partly) financed by the industry itself & 1 & 1 & 1 & 1 & 1 \\
\hline & Presence of artificial price interventions, potentially leading to overproduction & -1 & 1 & 1 & -1 & 1 \\
\hline & Costs of promoting more sustainable products are carried by the governing institution & -1 & 1 & 1 & -1 & 1 \\
\hline & Governance system is (partly) a form of foreign aid & 1 & 1 & 1 & -1 & 1 \\
\hline & Subtotal & 0 & 4 & 4 & -2 & 2 \\
\hline \multirow[t]{3}{*}{ Legitimacy } & Involvement of both upstream and downstream chain actors in decision making & 1 & -1 & -1 & -1 & 1 \\
\hline & Governing institution is represented by democratic institutions & -1 & -1 & -1 & 1 & -1 \\
\hline & Subtotal & 0 & -2 & -2 & 0 & 0 \\
\hline \multirow[t]{4}{*}{ Transparency } & Monitoring is performed along the complete production chain & 1 & -1 & -1 & 1 & 1 \\
\hline & Monitoring is performed by public or independent and transparent actor & 1 & -1 & -1 & 1 & 1 \\
\hline & Subtotal & 2 & -2 & -2 & 2 & 2 \\
\hline & Total & 6 & -2 & -3 & 3 & 6 \\
\hline
\end{tabular}

"1" Is considered a strength and a " -1 " a weakness. The more positive the total scoring, the better the governance system performs on these broader issue criteria. 
costs. The high score on dependency is due to the fact that this market is little distorted and governed by WTO rules. This model is also attractive to downstream actors as they get high and secured profits and have low costs. Apart from these strong points governance of the mainstream coffee market suffers from weaknesses as well. Concerning the sustainability standards the system performs mediocre to very poor (see Table 7). Moreover, it shows little attractiveness to producers as returns are low and volatile and the terms of trade often dictated by more upstream actors. Apart from this, monitoring of chain effects is poor.

\subsection{The fair trade coffee market}

The Fair Trade coffee market is a niche market in the sustainable coffee segment, with a retail value share of less than 1\% (in 2000) of the global coffee market (Ponte, 2004, p. 11). Fair Trade makes use of a consumer label and aims to improve the socio-economic conditions of and the terms of trade for small coffee farmers in developing countries (FLO, 2003a, p. 2). These objectives are pursued by issuing minimum green coffee prices, additional premiums, enhancing market access of producers by facilitating market transactions and strengthening producer associations through producer-supporting programs (Roozen and van der Hoff, 2002; Giovannucci and Koekoek, 2003, p. 38). The Fair Trade label and its standards are controlled by the Fairtrade Labelling Organization (FLO), which is comprised of grass root NGOs, an independent certification and verification company and an international NGO, coordinating the organization (FLO, 2003b, 2005). Decision making in the certification company and the administrative NGO is performed by elected stakeholders from the coffee chain (FLO, 2003b, 2005).

Without Fair Trade, coffee production would be similarly organized as the mainstream market, where autonomous small farmers from developing countries are contracted by powerful overseas traders and manufacturers (Ponte, 2002). The FLO, however, sets the rules of the game, limiting the "buying power" of the downstream traders, manufacturers and retailers, while increasing the power of producers, resulting in improved terms of trade. The FLO is the hub of the network, imposing and controlling standards and deciding who is eligible to enter the chain.

Tables 7 and 8 show that Fair Trade coffee scores high on many criteria. The governance system scores especially high on securing the socio-economic concerns (see Table 7). By certifying producers and licensing traders and retailers, most of the chain is controlled by the FLO. Together with independent certification, Fair Trade scores high on transparency. The producer's attractiveness is enhanced by spreading the cost of the certification system along the chain and fixing most risks and responsibilities in the chain, resulting in higher prices and more favourable terms of trade. By involving stakeholders in decision-making processes, the legitimacy of the system is enhanced.
Fair Trade scores weaker on sustainability concerns and costs. There are no minimal environmental standards (only progress requirements) and some (potential) cost-inefficiencies, such as minimum prices and promoting activities by the FLO. The attractiveness to downstream actors is poor, as profits are reduced, risks are fixed and investing in a non-privately owned label is risky. A major weakness is Fair Trade's dependency on conscious consumers paying a higher price, which severely limits the market size.

\subsection{The world sugar market}

The world sugar market is a residual market, which is heavily affected by regional and national (protective) sugar regimes (Alvarez and Polopolus, 2002, p. 2; FAO, 2003b, p. 4 ; NYBOT, 2005, p. 10). It is estimated that about $10-15 \%$ of global production is traded on the world market, whereas the rest is consumed domestically or traded under special arrangements (Alvarez and Polopolus, 2002, p. 2). But, as the WTO is making efforts towards liberalization of the regional sugar markets, it is expected that trade on the world market will increase significantly over time (Larson and Borell, 2001, p. 30; FAO, 2003b). For now, the world sugar market is characterized by chronic oversupplies, low and volatile prices and high price elasticities (Alvarez and Polopolus, 2002, p. 2). Market prices often drop below production costs and strengthen rationalization in the sugarproducing industry, which enhances (further) concentration of production (FAO, 2003b). World spot and futures markets determine prices and offer sophisticated financial and trading services (Larson and Borell, 2001, p. 2; NYBOT, 2005, p. 10).

The world sugar market is governed in buyer-driven fashion as the manufacturing and retailing nodes are very concentrated (McCorriston et al., 2004, p. 5). Generally, the world sugar chain is highly diversified, from production until retailing (IIED et al., 2004; Antony et al., 2004). Production can be organized by large integrated companies, which operate plantations or contract small farmers, but autonomous production by small farmers and processing can also be common (IIED et al., 2004, p. 69). Refined sugar is very versatile as end-uses of sugar are numerous, varying from food and beverages to energy and pharmaceutical purposes, so the manufacturing and retailing nodes are very diversified too. The food and beverages industry remains the largest consumer of sugar (IIED et al., 2004, p. 69; Neves et al., 2001, p. 5). However, the energy industry is an emerging consumer as the demand for ethanol rises sharply. The food and beverages industry is a highly concentrated sector, where a few multinationals control large market shares (IIED et al., 2004, p. 75). This in contrast to the more upstream nodes of processing, trading and production, which is fragmented and little concentrated. Manufacturers control the sugar chain, because of increased raw material flexibility and sheer market power (Gibbon, 2003, p. 19). As a response to this downstream dynamic, international traders are extending into upstream nodes (Gibbon, 2003, p. 19). There are, 
however, examples of downstream integration, especially by Brazilian companies and by producers in the developed world (Moss and Schmitz, 2002, p. 53; Kingsman, 2002; Antony et al., 2004).

Similar to the mainstream coffee case, addressing the sustainability concerns is mainly an issue for market actors. Standards, some of which are CSR based, are operated by (some) private companies, associations and exchange markets. ${ }^{1}$ However, the sustainability concerns are in general very poorly addressed by actors with substantial control over the world sugar market (see Table 7). Moreover, the world sugar market lacks transparency with regard to sustainability and sourcing policies. Monitoring takes place at only some nodes in the chain. The market is distorted by regional protectionist markets and is hardly attractive to producers due to low and volatile prices and unfavourable terms of trade. Strong points of world sugar governance are its low costs and its attractiveness towards downstream actors (see Table 8).

\subsection{The EU's sugar market}

The EU sugar market is in terms of global production and trade a significant market (FAO, 2003a; EC, 2003b, p. 53; EC, 2004, p. 22). This market is highly regulated and protected, where the supranational institutions of the EU, govern not only (sugar) trade, but also social and environmental issues related to sugar. EU sugar policy aims at a "fair" remuneration for producers and self supply of the EU market (EC, 2004). A host of instruments are used to stabilize the market at these levels, such as production quotas, minimum prices, levies, contractual arrangements, import barriers and export refunds (EC, 2004). As a result, however, EU sugar prices in 2005 where two to three times higher than world prices, access to the EU market is very limited and chronic oversupplies are dumped, partly with refunds, on the world market (EC, 2004; Larson and Borell, 2001, p. 6). This has put the EU under great pressure, both internally and externally, to reform their policy (Economist, 2005; WTO, 2005).

Overall, the organization of the production chain is rather heterogeneous as both buyer- and producer-driven characteristics emerge. Upstream nodes show some resemblance to a producer-driven chain, because of the large scale production systems and the vertical integration (EC, 2003). Sugar beet farms are on average relatively large compared to other crops and heavily mechanized (EC, 2003). Although producers and processors are favoured in the sugar regime, there is a trend of rationalization and concentration at the upstream nodes, driven by the search of increasing productivity (EC, 2003). Furthermore, due to the vertical integration of producers into the processing nodes most sugar production and processing is controlled

\footnotetext{
${ }^{1}$ Examples of companies are Unilever and Cargill; organizations are The Refined Sugar Association and The Sugar Association of London; exchange markets are NYBOT CSCE no.11 and LIFFE no. 5.
}

by a few dozen large producing companies (EC, 2003). The downstream chain is much diversified as sugar can be utilized for many purposes, but the food and beverages industry is the largest buyer of sugar (CIUS, 2005). These downstream nodes are very concentrated and occupied by huge multinational corporations, resembling a buyerdriven organization (IIED et al., 2004, p. 75). However, their buying power and upstream integration is severely limited, because of EU intermediation, consequently limiting their control over the supply chain and resulting in producer-driven characteristics upstream.

All but three sustainability concerns (leakage effects, land tenure and environmental additionality) are addressed in some way, although the scope and stringency varies considerably (Table 7). The Common Market Organization and the instruments of the Common Agricultural Policy regulating the market and incomes, provide a more general, although minimal, level of addressing the sustainability concerns. The rural development instruments target some specific farmers or areas and provide some extensive, but mostly voluntary, schemes addressing the sustainability concerns. As Table 8 shows, the EU sugar market scores rather high on other criteria (except on costs and attractiveness). The EU regulates the entire chain extensively by controlling key market factors, such as the production level, terms of trade, prices and trade barriers. This made integration of environmental care in the entire market and extensive monitoring possible. The downside, however, are the high cost due to price and trade interventions, despite self-financing mechanisms (i.e. producer levies that - partially - cover export subsidies). ${ }^{2}$ To downstream market actors the system is unattractive due to high sugar prices and trade restrictions. Towards EU producers, however, the governance system is attractive, as high sugar prices and terms of trade are relatively fixed. To non-EU producers, EU trade interventions and restrictions lead to low and volatile world sugar prices and poor access to the market.

\subsection{The FSC wood market}

International wood trade is relatively small $(6-8 \%)$ when compared to global production (Bass et al., 2001, p. 59). Wood production is increasingly certified, but markets remain small and fragmented (Atyi and Simula, 2002, p. 3; Bass et al., 2001, p. 26). FSC is one of the most successful international wood certification schemes and most successful in the Do-It-Yourself (DIY) retailing sector ${ }^{3}$ (Atyi and Simula, 2002; Bass et al., 2001; Taylor, 2005). The FSC certification and labelling scheme is a market-based instrument that is owned and operated by a multistakeholder NGO in which both actors of the wood products chain, individuals and organizations from civil society participate (FSC, 1998, p. xvi; Bass et al., 2001).

\footnotetext{
${ }^{2} \mathrm{CMO}$ sugar costs in 2004 where $€ 1,4$ bln (EC, 2004a, p. 6).

${ }^{3}$ Companies such as IKEA and Gamma (Dutch)
} 
According to FSC's view, global forest degradation is not attributed to the market itself, but to a lack of effective regulation (Bass et al., 2001, p. 5). By voluntary certification and third-party verification, forest management practices are supposed to be improved ecologically and socially, while remaining economically viable (FSC, 2005).

Although FSC is successful in penetrating the wood market, the market share remains limited as the label depends on conscious consumers. The FSC wood products chain is currently driven by large retailers from the DIY sectors, which are strongly represented in FSC's internal governance and buyers groups and have great market power (Bass et al., 2001; Taylor, 2005). As a result of this and due to the roots of the scheme in the conventional forestry market, existing trading patterns are not challenged by FSC, in contrast to the Fair Trade labelling scheme (Taylor, 2005, p. 135). Combined with a mainstreaming strategy pursuing rapid growth with little attractiveness to small- and community-based Southern producers, only $16-19 \%$ of the FSC certified forests lie in the South (Atyi and Simula, 2002, p. 3; Bass et al., 2001, p. 11). FSC certification is not very attractive for Southern producers, because certification proves to be a significant barrier of entry for those producers, as a result of the "producer pays" principle, a lack of a price premium and no assistance in commercialization. The most added-value seems to materialize at the retailing node, where actors profit from risk management and improved reputation (Taylor, 2005, p. 137).

FSC's standards for wood production addresses most sustainability concerns and FSC deals with many criteria (see Tables 7 and 8). The chain-of-custody certification ensures that end-users purchase wood products that come from FSC certified forests (enhanced monitoring). A framework of principles enhances the flexibility of the system, as nationally and/or locally relevant standards can be set. However, the overall added value of FSC as an instrument that protects world's forests and improves forest-management practices around the world may be questioned. Large-scale producers, with already good management practices, have relatively easy access to FSC markets, in contrast to Southern producers, for whom little markets are opened. Some classify the FSC scheme as a tool for improved marketing, instead as a tool principally for improving forest management (Councel and Loraas in Taylor, 2005, p. 142).

\section{A preliminary bio-energy governance system}

The previous evaluations provide the building blocks for designing a preliminary global bio-energy governance system. Because none of the case study governance systems is free of weaknesses, proposing a bio-energy governance system without weaknesses seems unrealistic. The proposal should, therefore, have minimal weaknesses and maximum strengths. Selecting the most promising (i.e. best performing) case study governance system seems a good start for this. Governance by FSC wood is regarded as the most promising for it secures the sustainability concerns (like a.s. deforestation and leakage effects) and other concerns best (see Tables 6-8). So, FSC governance is selected as the basis for the preliminary design. The weaknesses of this governance system can then be addressed by incorporating strong points of other case study governance systems and by creative thinking.

Although FSC is selected as the basis for the preliminary proposal, FSC has weaknesses too. Its fast growth strategy and retailer perspective, results in poor involvement and attractiveness towards Southern producers. In contrast to Fair Trade, FSC forms a significant barrier of entry for the Southern/small producers by using principles such as the "producer pays". By not interfering in price formations and trade relations, FSC is primarily attractive to downstream (leading) actors. Another significant challenge for FSC (and Fair Trade) is their dependency on conscious consumers, limiting trading volumes to niche market sizes.

To improve the attractiveness, a more balanced upstream-downstream perspective is designed, by incorporating additional instruments in the FSC-based proposal, such as price premiums, progressive certification and marketing assistance that are based on Fair Trade. Fair Trade challenges market mechanisms by favouring producers, by limiting control of the powerful downstream actors (e.g. minimum prices, favourable terms of trade and business facilitation). These instruments have a strong producer perspective, providing attractive perspectives for especially Southern producers. The downside of this perspective, however, is that the attractiveness to most downstream actors and consumers is lessened considerably, as high minimum prices limit the market. Therefore, multiple-level price premiums are proposed that are linked to the multiple levels of compliance (progressive certification). This helps to lower the barrier of entry for producers to participate in the certification scheme, but offers benefits to downstream actors at the same time, such as producer incentives to improve quality and avoidance of using controversial minimum prices. The attractiveness to small holder producers is further improved by facilitating marketing assistance (similar too Fair Trade), including possible certification subsidies.

In order to overcome the dependency on conscious consumers, neither FSC nor Fair Trade offer lessons to mitigate this weakness (except perhaps the FSC's buyers groups that mobilizes market actors to purchase FSC wood). The governance following the welfare state model like the CMO or the CAP do provide some clues. It is thought that governments could play a significant role in overcoming this weakness, by promoting the use of certified bio-energy, using several instruments. Governments can stimulate the use of certified bio-energy by (1) concluding covenants between governments and the industry on increasing certified bio-energy use, (2) setting certification as an import restriction of non-certified bioenergy and as minimal production standards for domestic 
production and (3) by implementing legislation that internalize environmental costs and benefits in market prices of energy. The latter instrument helps to bridge the price differential between certified and non-certified energy. In order to harmonize and coordinate the (implementation of) national instruments the development of an United Nations Agreement on Bio-energy (UNAB) is proposed.

Table 9 summarizes the preliminary two-pillar-based governance system. The 1st pillar, called the Bio-energy Labelling Organization (BLO), is formed by the complemented FSC certification system and the 2nd pillar is an UNAB in which governments intervene in order to overcome the BLO's reliance on conscious consumers. Instead of awaiting the implementation of a comprehensive UNAB, a private certification system may be operational within several years. Simultaneously, governments may start negotiating on the proposed UNAB. The growth of the BLO market may then benefit from extra momentum that is generated by the implementation of UNAB.

The BLO is a performance-based, voluntary and businessto-business certification system. The organization and internal governance of the BLO is similar to FSC, because this offers involvement and representation of stakeholders from both the industry and civil society, form both the developed and developing regions. The framework standards, which are based on FSC's Principles and Standards, are differentiated in national criteria by working groups. Ex ante impact assessments of production on local economies including food and energy supplies may show effects that better be mitigated. LCA studies may be used in order to ensure GHG additionality. Accreditation, certification and verification ask for the involvement of reputable independent organizations.

\section{Ex-ante evaluation and adjustments of the proposal}

In this paragraph the question is addressed whether the proposed governance system is suitable for the (antici- pated) unique and complicated global bio energy market, whether it will be politically feasible and whether it will comply with effectiveness conditions specified by experts. Although the proposal is based on the governance of commodities comparable to bio-energy, an ex-ante applicability evaluation is relevant, as the bio-energy market is unique in several respects. The bio-energy market has (1) an extreme feedstock versatility, (2) large supply potentials, (3) complex trading patterns, (4) many market links and (5) a difficult end-user valuation. By confronting the preliminary proposal with these market characteristics, the applicability of the proposal on a bio-energy market is assessed and possible adjustments are proposed.

\subsection{Extreme feedstock versatility}

The implication of the extreme feedstock versatility is that when all possible feedstocks are included in the scope of the $\mathrm{BLO}$, the standard setting might be challenging, because it would require participation of many varying industries. In principal, however, the sustainability criteria and certification system are assumed to be universal enough to accommodate the versatility. Therefore, the proposal is thought to be applicable to any feedstock. In order for the BLO to be manageable in the starting phase, however, the scope of the BLO can be limited to only the most significant feedstocks for bio-energy, used today and in the short term. Within time, this scope can be widened. It is also possible to limit the BLO to the most important sustainability concerns, which can be gradually expanded with more aspects.

\subsection{Large supply potentials and virtually infinite demand}

The large supply and demand potentials of (bio) energy may put an unprecedented amount of pressure on sustainability (e.g. impacts on land use and local economies). This demands a governance system that is broad of

Table 9

Main characteristics of the preliminary proposal

\begin{tabular}{|c|c|c|c|}
\hline Pillar & Instrument & Description & Purpose \\
\hline \multirow[t]{6}{*}{ BLO } & $\begin{array}{l}\text { Progressive } \\
\text { certification }\end{array}$ & Multiple levels of compliance on sustainability criteria & $\begin{array}{l}\text { Certification of production; Enables participation of } \\
\text { many producers }\end{array}$ \\
\hline & $\begin{array}{l}\text { Progressive price } \\
\text { premium }\end{array}$ & Linked to the level of compliance and product quality & $\begin{array}{l}\text { Incentive for producers to participate and to increase } \\
\text { the level of compliance }\end{array}$ \\
\hline & Impact assessments & $\begin{array}{l}\text { On local economy and food \& energy supplies and } \\
\text { GHG additionality using LCA studies }\end{array}$ & $\begin{array}{l}\text { Prevents leakage effects and food \& energy shortages; } \\
\text { ensures GHG additionality }\end{array}$ \\
\hline & Marketing assistance & $\begin{array}{l}\text { Advice programs on certification and organizing trade } \\
\text { relations; certification subsidies for small \& Southern } \\
\text { producers }\end{array}$ & $\begin{array}{l}\text { Enhances involvement of and benefits for small \& } \\
\text { Southern producers }\end{array}$ \\
\hline & Buyers groups & Actors from the industry and civil society & Stimulate the demand of BLO certified bio-energy \\
\hline & Monitoring & Chain-of-custody certification & Certification of trade \\
\hline \multirow[t]{3}{*}{ UNAB } & Covenants & Agreement between industries and governments & Increases use of BLO certified bio-energy \\
\hline & $\begin{array}{l}\text { National import and } \\
\text { production rules }\end{array}$ & Based on BLO certification & $\begin{array}{l}\text { Limits import and production of non-BLO certified } \\
\text { bio-energy }\end{array}$ \\
\hline & $\begin{array}{l}\text { Regulation of market } \\
\text { prices }\end{array}$ & Internalize environmental costs in prices of energy & $\begin{array}{l}\text { Lowers the price difference with unsustainable sources } \\
\text { of energy }\end{array}$ \\
\hline
\end{tabular}


scope and stringent in securing the sustainability concerns, in which many countries participate. Because FSC secures most of the sustainability concerns, these standards seem to be a good basis for the BLO. Alternative and complementary standards, partly based on Fair Trade, are proposed to further improve the performance of the FSC. The standard on deforestation, however, clashes with the expected dominance and expansion of plantations (FAO in WWF, 2000). ${ }^{4}$ In order to accommodate this, new plantations should only be allowed on abandoned agricultural land.

\subsection{Complex trading patterns}

Because bio-energy may be produced and traded from anywhere in the world, trading patterns may become extremely complicated. This may require many differentiated standards in order to accommodate the varying and unique ecological and socio-economic conditions of producing countries. Limiting the scope of the BLO to the most relevant bio-energy feedstocks (or sustainability concerns) might reduce this complication as well. Secondly, performing LCA studies in order to assess the GHG mitigation additionality on all unique flows of trade may be infeasible, as this may prove to be too time consuming and costly. This perhaps, depends on trading volumes and the number of end-uses. Alternatively, "GHG additionality indicators" may be used instead. Additionality may be indicated when a transaction meets a certain combination of these indicators (e.g. distance, feedstock, processing, end-use purposes, etc.). Traders can use these indicators exante (before the transaction of bio-energy takes place), while certification bodies verify the transactions ex-post. Although indicators are not waterproof, they do seem more practical and acceptable to the industry.

\subsection{Market links}

The many links of bio-energy to alternative markets may result in unwanted impacts on those (e.g. food shortages). Links with other markets may also imply an unfavourable opportunity costs structure, which makes supplying to alternative markets possibly more attractive. This may result in a barrier for involving producers in the BLO. The proposal is mainly aimed at controlling the supply side of bio-energy, by providing benefits for producers and traders and suggesting governmental intervention to support the BLO certification. The proposed governance system does not control the links with other markets. This can only be done by a meta-governance system for biomass.

\subsection{Difficult end-user valuation}

The difficult valuation of bio-energy by end-users points to a potential lack of interest by end-users and (conse-

\footnotetext{
${ }^{4}$ Plantations established after November 1994 are not eligible for certification (FSC criteria 10.9).
}

quently) the industry itself in sustainable bio-energy. The proposal curbs this potential problem by being indirectly, instead of directly, dependent on conscious consumers by using a business-to-business label. Dependency on endusers is further reduced by involving NGOs that pressures the industry, by providing (non-)monetary benefits for producers and by using governmental instruments that stimulate and ultimately forces the industry to use the BLO's certified bio-energy. Similarly to FSC, buyers groups are promoted in order to mobilize both end-users and the industry to use and/or produce certified bio-energy.

Although adaptations of the initial proposal are possible in order to better comply with the market characteristics, the interviewed experts are critical about the political feasibility of the preliminary proposal. At the moment, the UNAB is a bridge too far as countries have diverging views on sustainability and foreign politics (Geurts, 2005; Gupta, 2005; Van der Lee, 2005; Vermeulen, 2005). Developing and developed countries, for example, may have conflicting views on sustainability. With regard to foreign politics, countries can (either pursue a multilateral or an unilateral approach (Gupta, 2005). With regard to the BLO, the expert opinions are more various. Geurts and Gupta find the BLO less feasible, because of a supposed lack of interest by the industry to participate in BLO, many differentiated criteria would be needed to meet the geographically varying conditions of sustainability and producers already have trouble to keep up with the existing sustainability standards. Arguments in favour of the feasibility of the design are that the industry welcomes progressive certification and that implementing a private initiative is much more feasible on the short term than a global public initiative (Van der Lee, 2005; Vermeulen, 2005).

Experts opt for the development of an International Agreement on Bio-energy (IAB) by front running (Western) countries instead of an UNAB. Western countries are assumed to have less divergent views on sustainability and foreign politics and have already markets for sustainable production (Gupta, 2005; Van der Lee, 2005; Vermeulen, 2005).

According to the experts, our proposal meets the most important conditions enhancing the effectiveness of CSR based designs (Table 10). However, some communities may consider the proposal controversial, because expert opinions sometimes oppose each other. This also explains the inconsistency of the design with several conditions. Two conditions (the role of NGOs and barrier of entry) are met only partly by the proposal. For one, NGOs have decisionmaking power in the BLO, but monitoring activities are boarded to certification organizations. Secondly, adaptation of production and the certification process remains a barrier of entry in the view of Van der Lee, despite that the BLO features marketing assistance and possible certification subsidies.

The effectiveness of the preliminary proposal can be improved in three ways. First, the focus should be on the participation of large and front-running organizations. 


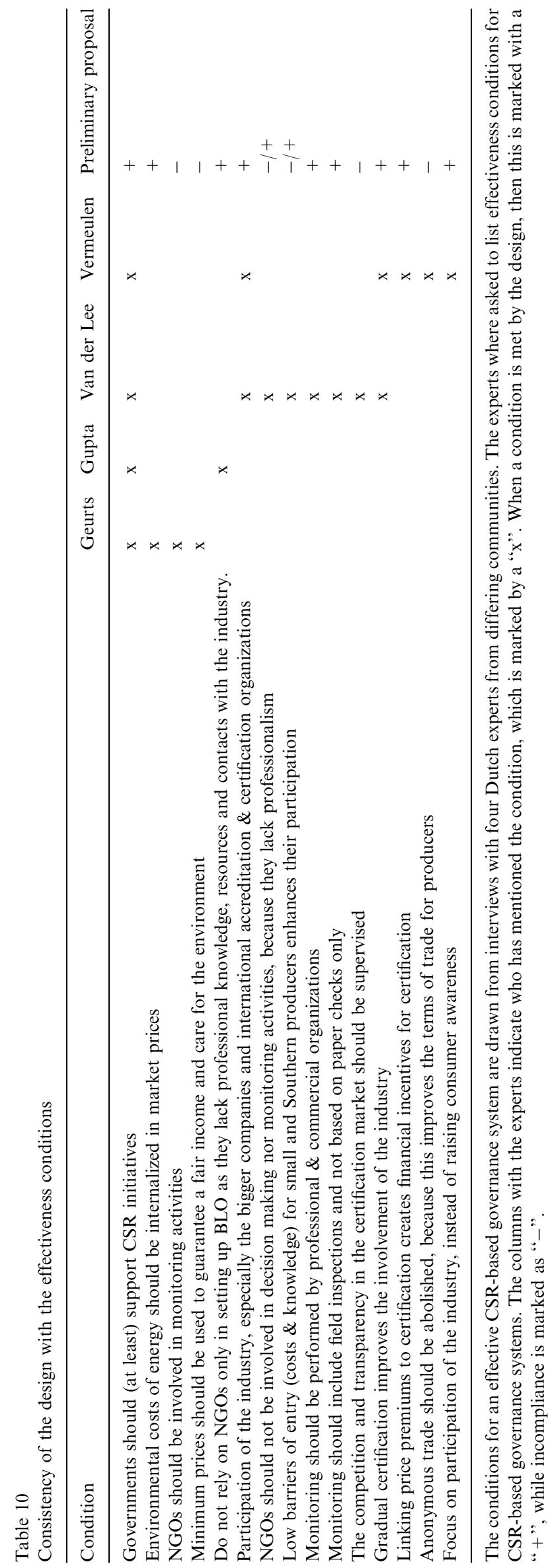

When front-runners and/or large organizations participate, the rest of the industry may follow by market pressure. Secondly, the institutionalization of a market supervisor is required as part of the IAB that guards transparency and competition (Van der Lee, 2005). And thirdly, producer micro-credits issued by development banks are suggested in order to further lower the barrier of entry for small holder producers. When the entry of barrier for producers is lowered by using higher (guaranteed) product prices, then the attractiveness for buyers is reduced (as prices rice).

Not all inconsistent effectiveness conditions have been met by these adjustments. Monitoring by NGOs is not institutionalized in the governance system, because it is assumed that companies will be able to do this more professionally. On the other hand, NGOs are involved in decision making, because they represent environmental and social interests. No minimum prices are proposed, because (1) there is little support from other experts and from the industry, (2) they are technically difficult to implement for many feedstocks and countries and (3) because of potentially high costs (of side effects). Abolishing anonymous trade by promoting face-to-face trade relations is not addressed in the design, because this seems impractical in the light of the voluminous and complex trading patterns of bio-energy. Instead, using trade certification including track-and-trace systems, trade patterns are made more transparent and less anonymous.

\section{Conclusions}

A perfect governance model does not seem to exist. The neo-liberal governance systems have difficulties in addressing the sustainability concerns, because sustainability policies are minimalist or even absent. The welfare state and CSR governance systems seem better able to address the sustainability concerns, because sustainability policies are generally well developed. The welfare state governance system shows that sustainability can be integrated in an entire market. However, a precondition to welfare state governance in an international context is that a supranational institution must exist, which is able to implement its policies. This may be unrealistic when regulation of international or global bio-energy trade and production is sought. The CSR governance systems perform relatively well, because they are more attractive, flexible and inexpensive, compared to the welfare state case study. Moreover, it lacks the need of a supranational institution. The FSC governance system is considered to be the most promising governance system in meeting the objective, because this governance system is able to address most sustainability concerns. However, major weaknesses are associated with the CSR governance systems. The most significant weakness is the dependency on conscious consumers, because the number of conscious consumers is generally limited. This is complicated by voluntary participation of market actors in the Fair Trade coffee and FSC wood markets. Additionally, FSC is less attractive to 
(especially) Southern and small producers, because of high barriers of entry. These weaknesses result in limited supply and demand. Our case studies reveal that a combination of the CSR and welfare state model is promising.

The first pillar of the combined proposal is formed by the CSR-based BLO, which offers a FSC-based certification system that is able to penetrate the market within a short time, offering stakeholder participation and standards that secure most sustainability concerns. By being compatible with neo-liberalism, the BLO seems acceptable to the industry and the WTO. The attractiveness for small and Southern producers is enhanced in this system using Fair Trade-based instruments, but remains in balance with downstream interests at the same time. The framework of universal sustainability principles enables geographical differentiation of standards and accommodation of numerous bio-energy feedstocks. Because the BLO suffers from dependency on conscious consumers, which is common to the CSR case studies, governmental intervention is proposed in order to realize a significant market penetration (the 2nd pillar). This intervention aims at enhancing the use of the BLO's certified bio-energy, by stimulating the industry using covenants, but also by using more coercive instruments like setting the BLO standards as production and import standard or internalizing environmental costs and benefits in energy prices. An International Agreement on Bio-energy (IAB) is proposed in order to coordinate the development and implementation of these instruments. A combined private (BLO) and public (IAB) initiative, can realize a fast and significant implementation of a bioenergy governance system in the market.

This proposal seems applicable to the bio-energy market, but to some issues attention should be paid. Initially, limiting the number of bio-energy feedstocks and/or the number of sustainability concerns helps to manage the BLO in its starting phase. Secondly, new plantations could be allowed when established on abandoned agricultural land. This helps to accommodate the future dominance of plantations. And thirdly, the usage of GHG mitigation indicators that assess the GHG balance of bio-energy are perhaps less expensive and time-consuming compared to LCA studies.

As a UNAB seems politically infeasible, we propose the development of an IAB in which front running (Western) countries participate. Western countries are assumed to have less divergent views on sustainability and foreign politics and have already markets for sustainable production.

The proposal meets most of the effectiveness conditions mentioned by the interviewed experts, such as the use of gradual certification and a supportive government. The perceived effectiveness is further enhanced by incorporating several additional adjustments in the proposal. A market supervisor should be institutionalized as this helps to guard the transparency and competition in the certification market. By focussing on involvement of leading actors, the entire industry can be "persuaded" to partici- pate in the BLO. And micro-credits issued by local development banks can be used to further lower the barrier of entry for small producers.

Some issues that may have impact on the conclusions must be noted. Firstly, the conclusions drawn about the feasibility and effectiveness of the design may not be supported by certain stakeholders and policymakers, because their opinions are not represented by the interviewed experts. Secondly, the sustainability concerns are drawn from literature and are not defined by using a stakeholder involvement process. The defined concerns may, therefore, not meet the needs of stakeholders in different ecological and socio-economic conditions. Thirdly, evaluation criteria are of course debatable. This evaluation must be regarded as a first attempt to evaluate the performance of governance systems. And finally, the description of the case studies relied for a great deal on the work of other researchers, which may have resulted in conclusions shaped implicitly by their perceptions. Much of the assessments, however, are based on primary research, so this impact may be limited.

\section{Recommendations}

We would like to conclude this article with some recommendations both concerning the policy debate on the issue, as well as dealing with the research agenda. Firstly, a broad debate on the future governance of bioenergy should be started or stimulated. This seems of cardinal importance, as the lack of an effective governance system, may turn bio-energy into a threat instead of an opportunity. Because market developments are uncertain, many interests are involved and numerous possibilities exist for governing bio-energy trade and production, it is important that this debate has a broad base in all domains of society. The proposed bio-energy governance system may serve as a starting point for such a debate. The participants of this debate should not be restricted to bioenergy stakeholders only, because bio-energy is an alternative market for many already existing food and energy markets, all of which are potentially affected by bio-energy developments. Secondly, in order to reduce the uncertainties surrounding the bio-energy market developments, the impacts of bio-energy on sustainability and on other markets, the organization of bio-energy markets and governmental energy policies should be monitored. In this way, the development of a future bio-energy governance system can be supported. Thirdly, future research on governance systems may support the debate too, especially as this research concentrates on questions like:

- What are the most relevant bio-energy feedstocks and/ or sustainability concerns that may be included in the BLO initially?

- Is it desirable to control the bio-energy market links to alternative markets? What meta-governance system for biomass could control these market links? 
- How do governance systems function in practice?

- Pilot studies and/or ex-ante evaluations help to further evaluate/develop the proposal. Suggested issues for testing are: Can the expected expansion of plantations be accommodated on abandoned agricultural land, without resulting in leakage effects, local energy and food supply shortages and conversion of natural habitats? What are the sustainability concerns according to stakeholders? What are the views of stakeholders on the proposal? What levels of compliance and price premiums are desirable/achievable?

- Which indicators can be used to determine the GHG additionality of bio-energy production and trade? How can these indicate the GHG additionality reliably?

- How can the IAB internalize environmental costs and benefits in energy market prices?

- What opportunities and threats result from WTO agreements for a bio-energy market governance system?

\section{Acknowledgments}

The authors acknowledge the interviewed experts G. Geurts (XminY Solidarity Fund, Amsterdam), Prof. Dr. J. Gupta (Vrije University, Amsterdam), G. van der Lee (Control Union, Rotterdam) and Dr. W. Vermeulen (Utrecht University, Utrecht). This publication has been made possible by the Dutch consultancy firm of Grontmij Netherlands B.V.

\section{References}

Alvarez, J., Polopolus, L.C., 2002. Domestic and International Competition in Sugar Markets. Institute of Food and Agricultural SciencesUniversity of Florida, Gainesville.

Antony, G., Prestwidge, D., Sandell, G., Archer, A., Thorburn, P., Higgins, A., 2004. Towards Farming-systems Change from Valuechain Optimization in the Australian Sugar Industry. Commonwealth Scientific and Industrial Research Organization (CSIRO), St. Lucia, Queensland, Australia.

Atyi, R.E., Simula, M., 2002. Forest Certification: Pending Challenges for Tropical Timber. ITTO Tropical Forest Update 12-3-2002.

Bass, S., Thornber, K., Markopoulos, M., Roberts, S., Grieg-Gran, M., 2001. Certification's Impacts on Forests, Stakeholders and Supply Chains. International Institute for Environment and Development, London.

Buckland, H., 2005, The oil for ape scandal, report by Friends of the Earth, The Ape Alliance, The Borneo Orangutan Survival Foundation, The Orangutan Foundation (UK) and the Sumatran Orangutan Society, published by Friends of the Earth Trust, London, United Kingdom.

Committee of Industrial Users of Sugar (CIUS), 2005. Website 〈www.cius.org〉, visited 16-09-2005.

Economist, The London, 2005. Beet a retreat, vol. 375, p. 73.

European Commission (EC), 2001. Green Paper: Towards a European Strategy for the Security of Energy Supply. Office for Official Publications of the European Communities, Luxembourg.

European Commission (EC), 2003a. Directive 2003/30/EC.

European Commission (EC), 2003b. Sugar international analysisproductions structures within the EU, from website 〈europa.eu.int〉, visited 15-9-2005.
European Commission (EC), 2004. EU sugar sector: facts and figures, from website 〈europa.eu.int〉, visited 25-9-2005.

Faaij, A., Remmers, R., Wagener, M., 2003. Proposal for a new task within the bio-energy agreement. Website 〈www.fairbiotrade.org〉, visited 12-11-2004.

Fairtrade Labelling Organization International (FLO), 2003a. Generic Fairtrade Standards for Small Farmers' Organizations-version January 2003. Website 〈www.fairtrade.net>, visited 6-3-2005.

Fairtrade Labelling Organization International (FLO), 2003b. FLO Trader Application Evaluation Policy-version 3.2. Website <www. fairtrade.net $>$, visited 6-3-2005.

Fairtrade Labelling Organization International (FLO), 2005. Website 〈www.fairtrade.net>, visited 2-2-2005.

Food and Agriculture Organization of the United Nations (FAO), 2003a. FAO's participation in the Fifth WTO Ministerial Conference, Cancun, Mexico-Important Commodities in Agricultural Trade: Sugar. FAO, Rome.

Food and Agriculture Organization of the United Nations (FAO), 2003b. FAO Agricultural Commodity Projections to 2010. FAO, Rome.

Forest Stewardship Council (FSC), 1998. FSC National Initiatives Manual, website <www.fsc.org >, visited 22-10-2005.

Forest Stewardship Council (FSC), 2005. Website 〈www.fsc.org $\rangle$, visited 22-10-2005.

Gereffi, G., Korzeniewicz, M. (Eds.), 1994. Commodity Chains and Global Capitalism. Praeger Publishers, Westport.

Geurts, G., 2005, Interview on 21-10-2005, XminY Solidariteitsfonds, Amsterdam.

Gibbon, P., 2003. Commodities, Donors, Value-chain analysis and Upgrading. Danish Institute for International Studies, Copenhagen.

Giovannucci, D., Koekoek, F.J., 2003. The State of Sustainable CoffeeA study of Twelve Major Markets. ICO and IISD, London and Winnipeg.

Goldemberg, J., Johansson, T.B., 2004. World Energy AssessmentOverview 2004 Update. United Nations Development Programme, New York.

Gupta, J., 2005. Telephonic Interview on 11-11-2005. Institute for Environmental Studies (IVM), Amsterdam.

Hoogwijk, M., 2004. On the global and regional potential of renewable energy sources, Thesis Utrecht University.

Hoogwijk, M., Faaij, A., van den Broek, R., Berndes, G., Gielen, D., Turkenburg, W., 2003. Exploration of the ranges of the global potential of biomass for energy. Biomass and Bioenergy 25, 119-133.

IIED, ProForest and the Rabobank, 2004. Better Management Practices for IFS and WWF-US - Phase 2 Commodity Guides. Website $\langle$ www.iied.org >, visited 20-9-2005.

International Coffee Organization (ICO), 2001. Environmental issues relating to the coffee chain within a context of trade liberalization, through a LCA approach, London.

International Trade Centre (ITC), 2005. The Coffee Guide. Website $\langle$ www.intracen.org/thecoffeeguide/welcome.htm 〉, UNCTAD and WTO, visited on 31-05-2005.

Kingsman, S.J., 2002. Website 〈www.sugaronline.com〉, visited on 6-62005.

Kolk, A., 2005. Corporate social responsibility in the coffee sector-the dynamics of MNC responses and code development. European Management Journal 23, 228-236.

Larson, D.F., Borell, B., 2001. Sugar Policy and Reform. The World Bank, Washington, DC.

Lewandowski, I., Faaij, A., 2004. Steps Towards the Development of a Certification System for Sustainable Bio-energy Trade. Utrecht University, Utrecht.

Lewin, B., Giovannucci, D., Varangis, P., 2004. Coffee Markets-New Paradigms in Global Supply and Demand. The World Bank, Washington, DC.

McCorriston, S., Sexton, R.J., Sheldon, I.M., 2004. Vertical market structure, commodity exports and trade reform. Paper presented at Seventh Annual Conference on Global Economic Analysis, World Bank, Washington, DC. 
Midttun, A., 1999. The weakness of strong governance and the strength of soft regulation: environmental governance in post-modern form. Innovation-The European Journal of Social Sciences 12, 235-250.

Midttun, A., 2004. Realigning business, government and civil society: the $\mathrm{C}(\mathrm{S}) \mathrm{R}$ model compared to the (neo)liberal and welfare state models. Paper for the Third Annual Colloquium of the European Academy of Business in Society, Gent, Belgium.

Moss, C.B., Schmitz, A., 2002. Vertical integration and trade policy: the case of sugar. Agribusiness 18, 49-60.

Neves, M.F., Zylberstajn, D., e Castro, L.T., 2001. Strategic alliance in the sugar chain: the case of Crystalsev. International Food and Agribusiness Management Association, Texas.

New York Board of Trade (NYBOT), 2004. Coffee-Futures and Options. World Financial Center, New York.

New York Board of Trade (NYBOT), 2005. Agricultural Futures and Options. World Financial Center, New York.

Ponte, S., 2002. The 'Latte Revolution'? Regulation, Markets and Consumption in the Global Coffee Chain. World Development 30, 1099-1122.
Ponte, S., 2004. Standards and Sustainability in the Coffee Sector-A Global Value Chain Approach. International Institute for Sustainable Development, Winnipeg.

ProForest, 2003. Discussion paper for the Round Table on Sustainable Oil Palm, Oxford.

Roozen, N., van der Hoff, F., 2002. Fair Trade-Het verhaal achter Max Havelaar koffie, Oké-bananen en Kuyichi-jeans. Uitgeverij Van Gennep, Amsterdam.

Taylor, P.L., 2005. In the market but not of it: Fair Trade Coffee and Forest Stewardship Council certification as market-based social change. World Development 33, 129-147.

Van der Lee, G., 2005. Interview on 28-11-2005. Control Union, Rotterdam.

Vermeulen, W., 2005. Interview on 06-12-2005. Utrecht University, Utrecht.

World Trade Organization (WTO), 2005. Website 〈www.wto.org〉, visited 2-4-2005.

World Watch Institute (WWI), 2006. State of the World: Special Focus: China and India. Washington, DC.

World Wide Fund for Nature (WWF), 2000. The Forest Industry in the 21st Century. Website〈www.wwf.org.uk〉, visited 9-11-2005. 